\title{
Ergonomics Contributions to Company Strategies
}

\author{
Jan Dul and W. Patrick Neumann
}

Accepted in Applied Ergonomics

\begin{tabular}{|l|l|}
\hline \multicolumn{2}{|l|}{ ERIM REPORT SERIES RESEARCH IN MANAGEMENT } \\
\hline ERIM Report Series reference number & ERS-2008-058-LIS \\
\hline Publication & September 2008 \\
\hline Number of pages & 32 \\
\hline Persistent paper URL & http://hdll.handle.net/1765/13213 \\
\hline Email address corresponding author & jdul@rsm.nl \\
\hline Address & Erasmus Research Institute of Management (ERIM) \\
& RSM Erasmus University / Erasmus School of Economics \\
& Erasmus Universiteit Rotterdam \\
& P.O.Box 1738 \\
& 3000 DR Rotterdam, The Netherlands \\
& Phone: + 31 10 408 1182 \\
& Fax: $\quad+31104089640$ \\
& Email: info@erim.eur.nl \\
& Internet: $\quad$ www.erim.eur.nl \\
\hline
\end{tabular}

Bibliographic data and classifications of all the ERIM reports are also available on the ERIM website: www.erim.eur.nl 


\section{ERASMUS RESEARCH INSTITUTE OF MANAGEMENT}

\section{REPORT SERIES}

\section{RESEARCH IN MANAGEMENT}

\begin{tabular}{|l|l|}
\hline ABSTRACT AND KEYWORDS \\
\hline Abstract & $\begin{array}{l}\text { Managers usually associate ergonomics with occupational health and safety and related } \\
\text { legislation, not with business performance. In many companies, these decision makers seem not } \\
\text { to be positively motivated to apply ergonomics for reasons of improving health and safety. In } \\
\text { order to strengthen the position of ergonomics and ergonomists in the business and } \\
\text { management world, we discuss company strategies and business goals to which ergonomics } \\
\text { could contribute. Conceptual models are presented and examples are given to illustrate: 1) the } \\
\text { present situation in which ergonomics is not part of regular planning and control cycles in } \\
\text { organizations to ensure business performance, and 2) the desired situation in which ergonomics } \\
\text { is an integrated part of strategy formulation and implementation. In order to realize the desired } \\
\text { situation, considerable changes must take place within the ergonomics research, education and } \\
\text { practice community by moving from a health ergonomics paradigm to a business ergonomics } \\
\text { paradigm, without losing the health and safety goals. }\end{array}$ \\
\hline Free Keywords & corporate strategy, system performance, paradigm shift \\
\hline Availability & $\begin{array}{l}\text { The ERIM Report Series is distributed through the following platforms: } \\
\text { Academic Repository at Erasmus University (DEAR), DEAR ERIM Series Portal } \\
\text { Social Science Research Network (SSRN), SSRN ERIM Series Webpage } \\
\text { Research Papers in Economics (REPEC), REPEC ERIM Series Webpage }\end{array}$ \\
\hline Classifications & $\begin{array}{l}\text { The electronic versions of the papers in the ERIM report Series contain bibliographic metadata } \\
\text { by the following classification systems: } \\
\text { Library of Congress Classification, (LCC) LCC Webpage } \\
\text { Journal of Economic Literature, (JEL), JEL Webpage } \\
\text { ACM Computing Classification System CCS Webpage } \\
\text { Inspec Classification scheme (ICS), ICS Webpage }\end{array}$ \\
\hline
\end{tabular}




\title{
Ergonomics Contributions to Company
}

\section{Strategies}

\author{
Jan Dul'* and W. Patrick Neumann² \\ ${ }^{1}$ Department of Management of Technology and Innovation, \\ Rotterdam School of Management, Erasmus University, PO Box 1738, 3000 DR \\ Rotterdam, The Netherlands \\ ${ }^{2}$ Department of Mechanical and Industrial Engineering, Ryerson University, 350 Victoria \\ St., Toronto, ON, Canada, M5B 2K3
}

Re-submitted to: Applied Ergonomics

June 24, 2008

\footnotetext{
* Corresponding author:

Jan Dul

Professor of Technology and Human Factors,

Department of Management of Technology and Innovation,

Rotterdam School of Management, Erasmus University,

PO Box 1738, Room T10-55,

3000 DR Rotterdam, The Netherlands.

Ph. + 31-104081932; Fax + 31-104089014

e-mail: jdul@rsm.nl
} 


\begin{abstract}
Managers usually associate ergonomics with occupational health and safety and related legislation, not with business performance. In many companies, these decision makers seem not to be positively motivated to apply ergonomics for reasons of improving health and safety. In order to strengthen the position of ergonomics and ergonomists in the business and management world, we discuss company strategies and business goals to which ergonomics could contribute. Conceptual models are presented and examples are given to illustrate: 1) the present situation in which ergonomics is not part of regular planning and control cycles in organizations to ensure business performance, and 2) the desired situation in which ergonomics is an integrated part of strategy formulation and implementation. In order to realize the desired situation, considerable changes must take place within the ergonomics research, education and practice community by moving from a health ergonomics paradigm to a business ergonomics paradigm, without losing the health and safety goals.
\end{abstract}

\title{
Keywords
}

Corporate strategy, system performance, paradigm shift 


\section{Introduction}

The value of ergonomics extends beyond health and safety. This discussion paper emphasizes how --while maintaining health and safety of consumers and workers-- ergonomics can support a company's business strategy to stay competitive. For this discussion we employ the broad definition of ergonomics, proposed by the International Ergonomics Association (IEA):

"Ergonomics (or human factors) is ... concerned with the understanding of interactions among humans and other elements of a system, ... in order to optimize human well-being and overall system performance." (IEA Council, 2000).

The definition implies that ergonomics has both a social goal (well-being) and an economic goal (total system performance); that ergonomics considers both physical and psychological human aspects; and that ergonomics is looking for solutions in both technical and organizational domains. Performance aspects could include output volume, lead time, production flexibility, quality levels and operating cost among others.

\subsection{The Problem of Ergonomics}

During the past 25 years, several authors have emphasized that ergonomics has had a problem being accepted by business managers. In an essay in the Administrative Science Quarterly, Perrow (1983) argued that the problem of ergonomics is that too few ergonomists work in companies; that they have no control over budgets and people; and that they are seen solely as protectors of workers, rather than builders of systems - for example by not blaming human errors on workers but on designers and managers instead. Hal Hendrick, the former president of the International Ergonomics Association (IEA), wondered "Why it is ... that more organizations, with their strong need to obtain employee commitment, reduce expenses, and increase productivity, are not banging down our doors for help..." (Hendrick, 1996, p 2). He suggested that there are too many examples of bad ergonomics, that ergonomists -wronglypresume that others are convinced of the importance of ergonomics, and that the benefits of ergonomics are not well documented. 
Another major concern among ergonomists is that ergonomics is considered too late in the design process (Breedveld and Dul, 2005; Helander, 1999; Imbeau, 2001; Jensen, 2002). Once strategic design decisions about products or processes have been made, the majority of resources are already committed so that the cost for any change increases dramatically (Miles and Swift, 1998). Under these circumstances, only minor 'ergonomic' adaptations and corrections can be made and ergonomics is experienced as a time-consuming and costly activity. In such situations, the potential of ergonomics to contribute positively to the design is limited.

Managers generally do not associate ergonomics with organizational effectiveness, but rather with health issues (Jenkins and Rickards, 2001) and related costs of sickness absence and disorders, although even the contribution of ergonomics to health and safety is not always recognized. Managers are not to be blamed for that. It appears that ergonomists hardly ever write articles on ergonomics in business and management journals (Dul 2003a), limiting the possibilities to expand the management community's perception of the many benefits available via ergonomics. The few articles that refer to ergonomics confirmed to readers that ergonomics has a limited scope (physical ergonomics). Furthermore, in many countries, ergonomics is closely linked to occupational health and safety legislation. Discussions in the USA on OSHA'S 'Ergonomics Rule' gave the general public and managers the impression that ergonomics is about work-related musculoskeletal disorders; and that prevention of these disorders is a heavy financial burden for companies, resulting in debates on the costs of ergonomics and the validity of ergonomics knowledge, and in explicit negative publications denouncing ergonomics (e.g. Scalia, 2001). Applying ergonomics solely to fulfil health and safety or legislative objectives may be only a 'negative' motivator for managers: that is, fear of negative consequences such as sick leave, accidents and associated costs. Then, managers often outsource the responsibility for healthy employees and safe work to a health and safety consultant or department. Indeed, most often ergonomists themselves work on the basis of a health and safety paradigm and focus on workplace hazards (Whysall et al, 2004).

\subsection{Direction for a Solution}


We argue that the present situation, where ergonomics is linked to health and safety should not be the only basis for applying ergonomics in organizations. We suggest that if ergonomics contributes directly to the company's strategy, and in the language of the company, it will be more accepted by business managers; it will be better embedded (internalised) in the organization; and its full potential as described in the IEA definition will be better actualized (Dul and Neumann, 2005). Also it will be easier to obtain health and safety improvements, if managers understand that the ergonomic improvements will simultaneously help them realise their primary strategic business goals.

Currently many managers and ergonomists may not be used to thinking in terms of the strategic objectives within the firm and the strategic opportunities provided by ergonomics to help reach core business goals. In this paper, we will explore new opportunities and challenges for ergonomics by describing possible relationships between ergonomics and company strategies. Our goal is to present a broad overview of possible business strategies to which ergonomics research, education and practice could be linked, rather than describing the links in detail. This paper also should support ergonomists in their efforts to develop their 'business' language so as to improve their ability to communicate with the business and management world.

\section{Strategy and Ergonomics}

'Strategy' may be a useful connection point through which organizations might begin to internalise ergonomics because strategy a) has top management priority and, b) is normally broadly communicated and implemented in the organization. Connecting ergonomics to the company's strategy may provide managers with a more 'positive' motivation to apply ergonomics: not only can ergonomics create opportunities for safe and healthy work, but it can also improve system performance.

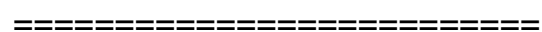


We consider strategy as the combination of 'strategy concept' (the formulation of a course of action for reaching business goals) and 'strategy implementation' (realization of this concept).The upper part of Figure 1 shows a simplified relationship between the formulated strategy concept ("theory"), its implementation ("practice"), and the business outcomes. Several types of desired business outcomes can be distinguished. For this discussion, we consider three groups of business outcomes: ultimate financial business goals (e.g. turnover, profit); and two groups of intermediate business goals, effectiveness (e.g. quality) and efficiency (e.g. productivity). Firms typically use feed forward and feedback systems of dynamic planning and control cycles, including business plans, targets, evaluations, rewards, etc., to guarantee that ultimate and intermediate business outcomes will be realized.

\subsection{Setting the Stage for Strategic Ergonomics}

Ergonomics is usually not part of the primary strategy to reach desired business outcomes and their related planning and control cycles. As argued above, ergonomics is often considered as separate from the main strategic objectives of the company and forced by legislation, which is a view that may be shared by both managers and health and safety professionals. This is shown in the lower part of Figure 1. In companies, ergonomics is typically linked to occupational health and safety (OHS) goals and to a company's obligation to fulfil OHS legislation, and therefore may be delegated to health and safety departments who are not connected to strategic decision making processes. Feedback to managers may eventually come in the form of injuries, absenteeism, and labour turn-over, or ultimately from labour inspection. This feedback typically comes with a delay, long after the design is implemented, so it may never reach design teams (Perrow 1983). Feedback delay inhibits effective management and organisational learning (Senge, 1990).

\section{INSERT FIGURE 2 ABOUT HERE}

In order to stimulate the uptake of ergonomics, without relying on OHS legislation, it seems necessary to explicitly relate ergonomics to business strategy. This is shown in Figure 2 by the 
arrows from 'Ergonomics' to 'Strategy concept' and 'Strategy implementation', and business outcomes. If it can be shown that ergonomics is related to strategy, ergonomics will be considered as a tool to realize desired business outcomes as shown by the arrows from 'Strategy concept' and 'Strategy implementation' to 'Ergonomics' and from 'Ergonomics' to 'Business goals'. In order to further explore how ergonomics can be linked to strategy we first divide the general concept of strategy into strategic 'arenas' within the firm.

\subsection{Strategy Arenas}

To be able to focus more precisely on how ergonomics can be capitalized on within an organization, we split strategy into strategy arenas and list these here in sequence of increasing scope:

1) Business Function Strategies: Each business function, such as Product Design, Operations, Marketing, Human Resource Management, or Finance will have their own strategic goals. Middle managers and employees from these business functions often have different 'languages' of their daily business. Here, ergonomics must show that it can support the chosen strategies, tactics and performance indicators of the functional field.

2) Cross-functional strategies: Cross-functional strategies involve two or more business functions; hence, several corresponding middle managers and employees from these business functions will be primary stakeholders. Total Quality Management (TQM) is an example of a cross-functional strategy affecting several business funtions. Ergonomics must show here that it can add value to the crossfunctional strategies and tactics.

3) Corporate Strategy: In the corporate strategy arena, the top management of the organization is involved, as well as external stakeholders including shareholders. An example of a corporate strategy is a Cost Strategy in order to compete on the basis of low costs. Here ergonomics must show that it can add value to the corporate business strategy for realizing competitive advantage. 
Each strategic arena represents a different set of stakeholders that might affect the way ergonomics is implemented (Neumann et al. 1999). The key decision makers in each area will be influenced by people, agendas, and information from both inside and outside the company. For each strategic arenas, we discuss opportunities for ergonomics.

\section{Business Function Strategies and Ergonomics}

While there are many different business functions to which ergonomics can be linked, this paper we will focus on the link between ergonomics and Product Design and Innovation, Operations Engineering and Process Innovation, Marketing and Communication, and Human Resource Management.

\subsection{Product Design and Innovation}

The business function, 'product design', refers to the design of improved or new products. Companies, in particular in the western world, are increasingly aware that innovation is essential for maintaining a competitive advantage. As all innovations start with a creative idea (Amabile et al. 1996), it has been acknowledged that end users of products and services can be important resources for product design and innovation (Kristensson et al., 2002; Von Hippel, 1986). In the tradition of product ergonomics, user involvement is considered as essential for the development of user-friendly product and services, and the participatory design methods and tools that have been developed in the ergonomics could be useful for linking ergonomics with product innovation.

Ergonomics can not only be used for designing products that fit the needs of end users, but also for the design of products that are easy to produce (Broberg, 1997). Many times products are not designed to accommodate the physical or mental characteristics of the target customer (Norman, 2002). By linking CAD product design information with biomechanical models, it is possible to evaluate the physical load of the user as a design changes, for example in designing a car interior (Kuo an Chu, 2005) .

Design for Assembly (DfA) or Design for Manufacturability (DfM) (Helander and Nagamachi, 1992) is an approach by which the ergonomics of assembly is considered in the 
product design stage. By considering production ergonomics in the product design phase, it is possible to avoid all costs associated with corrective ergonomics processes with little extra investment in the design phase. This objective is proving difficult to achieve, although some signs of success here have been reported (Munck-Ulfsfält et al., 2004). Ford, in its corporate ergonomics process, systematically identifies ergonomics problems observed on the floor and directs them to product design teams so the problem can be designed out of future models (Joseph, 2003). Such a feedback approach can support learning amongst the design teams. Sundin et al. (2004) have combined participatory ergonomics approaches with virtual visualization techniques to test and improve product designs for better ergonomics and efficiency in assembly. Hence, ergonomics can be linked to strategies for product design and innovation by assuring that the products fit with the end-users and are easy to produce.

\subsection{Operations Engineering and Process Innovation}

The 'operations' business function (including production engineering and logistics), determines to a large extent how the operating system is designed. Consequently this function determines the work tasks of operators and its distribution over the working day - essentially defining the ergonomic conditions of the system (Neumann et al., 2002, 2006). There are many different strategic goals that the operations function might prioritise including: throughput time, machine or operator utilisation rates, work in process levels, capital cost, operating costs, system reliability and robustness, flexibility and variant accommodation to name a few. These strategic aims are then met through, what Brassler and Schneider (2001) call, "a bundle of interconnected measures" relating to material and information flows, division of labour, technology and layout choices.

Ergonomics can help to allocate tasks to either people or machines; and to design the system elements in such a way that production system goals are realized without adverse affects for the human operator. For example, in a recent study of 20.000 warehouse orderpicks, Larco et al. (2008) showed that human well being and economic goals come together. While end-users may be 'experts' for product innovation, employees maybe 'experts' for process innovation. Employees at any level of the organization are a potential resource for 
creativity and innovation (Eisenberger, 1990; Shalley et al. 2004). Employee creativity (including the creativity of designers and engineers) can be enhanced by stimulating organizational and physical work environments. Production ergonomics, with its focus on designing humancentered work environments, can therefore be linked to process innovation (Ceylan et al. 2008; Dul and Ceylan, 2006; Dul et al., 2007). Hence, ergonomics can be linked to strategies for operations engineering and process innovation in order to assure that both production goals and worker well-being are safeguarded.

\subsection{Marketing and Communication}

The 'marketing and communication' business function deals, amongst other things, with branding of products and services.

Ergonomic products have characteristics like functionality, usability, safety, and comfort, which have positive associations that can be communicated to the customer. Furthermore, ergonomically produced products and services may, similar to 'fair trade' or 'green' products and production processes, target the aware consumer. Ergonomics can be presented as a part of a company's 'corporate social responsibility' and 'corporate sustainability' platforms (Hardjono and De Klein, 2004), particularly when increasing demands are placed on companies to be more than money-making organizations. Thus, the advertising of ergonomics as part of the 'sustainable product' or 'sustainable production' campaigns (Swaen and Vanhamme, 2004) can offer the potential consumer a better product, made in better working conditions, for a better world. A barrier here remains the extent to which a) consumers are prepared to differentiate products based on the working conditions of their manufacture, and b) credible information on the working environment is available. Another perspective here is communication with investors where work environment reports are being used to demonstrate commitment to long-term profitability as means to sell company shares (Goldschmidt et al., 2002). Thus, ergonomics can be linked to marketing and communication strategies by providing reasons for positive (wellbeing) consumer associations with the company's products and production processes.

\subsection{Human Resource Management}


The Human Resource Management (HRM) business function primarily deals with the selection and development of the people in the organization. HRM has long been held responsible for working conditions and employee well-being, even though this function tends to have little authority over work system design. The gap between human resources and operations management $(\mathrm{OM})$ has been noted and presents a challenge for the design of work systems that are motivating and productive (Boudreau et al., 2003; Gino and Pisano, 2008). Having good working conditions presents one strategy for attracting and retaining high-quality employees. The need to attract people to manual assembly jobs in Sweden was one of the driving forces of production system innovation away from traditional Tayloristic line production toward new more productive and attractive solutions (Ellegård et al., 1992). Ergonomics has a long tradition in assuring working conditions for human well-being.

Another HRM strategy is 'High Performance Work Systems' (HPWS), which incorporates elements of employee involvement and empowerment (Den Hartog and Verburg, 2004). HPWS can increase organizational performance (Appelbaum et al., 2000; Datta et al., 2005; Preuss, 2003; Way, 2002), but appears to operate on the HR side of the HR-OM gap. Ergonomics could help bridge this gap as it explicitly includes perspectives of both the human and the work system and carries good workplace design as one of its primary objectives (Helander, 2006). Furthermore, ergonomics can contribute to HPWS with its "participatory ergonomics" (Noro and Imada 1991) and job design approaches.

Hence, ergonomics can be linked to HRM strategies by assuring good working conditions and by engaging in participatory and job design approaches.

While this is not a complete list of all business functions that may exist in a particular organization to which ergonomics might be linked (Dul, 2003a; Dul and Neumann 2005, Ekman Philips, 1990; Neumann et al., 1999), these brief descriptions show that ergonomics can be linked to a range of business functions and hence to the objectives of its stakeholders.

\section{Cross-functional Strategies and Ergonomics}

We identify 'cross functional' strategies as a separate aspect of strategy due to the large scope and complex dynamics of strategic processes that span several business functions. In this 
paper we examine the strategies 'Lean Production, Business Process Re-engineering, Downsizing', and Total Quality Management. For these strategies to be successful, several business functions must work together to realize an effective implementation. The potential of ergonomics to contribute to each separate business function (see above) may serve as a tool to bridge and integrate business functions.

\subsection{Downsizing, Lean Production, Business Process Re-engineering}

Downsizing, Lean Production and Business Process Re-engineering focuses on radical improvements of business processes in order cut costs and serve customers better. This strategy has received attention from ergonomics because implementations of this strategy can result in reduced employee well-being. For example, Vahtera et al. (1997) have found risk of musculoskeletal disorders to increase by 5.7 times during 'corporate downsizing'. The individual's perception of the downsizing process itself also appears to affect health (Kivimäki et al., 2001; Pepper et al., 2003). Landbergis et al. (1999), in their review of available literature, noted increased negative health outcomes are often associated with the implementation of Lean Manufacturing approaches. In a longitudinal study implementation of lean production was shown to result in job depression and reductions in job control and skill utilization (Parker, 2003). While it is tempting to look at these results and say: 'Downsizing, Lean Production and Business Process Re-engineering is bad ergonomics', this is perhaps not the right conclusion. As our model (Figure 1) points out, strategy includes both a concept and its implementation. While the extent and the manner in which a strategy is realized may vary (Adler and Goldoftas, 1997; Ghobadian and Gallear, 2001; Womack, 1990); it is the gap between strategy and practice that may be a more important indicator of (poor) performance than the strategy itself (Rho and Yu, 2001). Conti et al. (2006) in a study of 21 different UK companies found that employee stress related to lean implementations was related to implementation and operational decisions rather than inherent problems with the Toyota Production System / 'lean' model that, according to former Toyota president Fujio Cho, strongly emphasises reducing operator burden (Liker, 2004). It is difficult therefore to determine the ergonomic consequences of strategies directly, without considering the specific implementation for each case. Hence, ergonomics 
may help companies to control the negative human effects of the Downsizing, Lean Production and Business Process Re-engineering strategy in order to obtain the real benefits from this strategy.

\subsection{Total Quality Management}

Total Quality Management (TQM) is a cross-functional strategy for improving business processes by incremental improvements, involving 'all' employees and 'all' business functions. For the implementation and management of this strategic concept, specific tools can be used. Many European organizations use the EFQM model (European Foundation for Quality Management), which has a Resource Based View (see below) on quality (Ruiz-Carrillo and Fernández-Ortiz, 2005). In this model, nine criteria for quality are considered, including two for people (people enablers and people results). Eskildsen and Dahlgaard (2000) showed that people enablers (e.g. HRM practices) lead indeed to people results (e.g., job satisfaction). Ergonomics can be readily applied to the people enablers of quality, in order to increase quality.

Quality has links to workplace ergonomics (Carayon et al., 1999; Drury, 2000; Eklund, 1995; Joseph, 2003; Lee, 2005). According to Drury (2000), quality is a function of technological and human factors, and is greatly influenced by ergonomics in its broadest sense. Errors in the process can result in product unreliability, poor productivity or even injury to the workforce or product user. A number of empirical studies confirm this view (e.g. Axelsson 2000; Lin et al. 2001; Sen and Yeow 2003; Yeow and Sen 2005). Thus, ergonomics may contribute to TQM by ensuring that people contribute to quality.

\section{Corporate Strategies and Ergonomics}

\subsection{Differentiation Strategy}

According to Porter (1985) a differentiation strategy is one way that a company can use to create competitive advantage. With a differentiation strategy, the company produces and delivers products or services with unique features to attract consumers. 
User-friendly or error-free products, created by ergonomic product design, can be such feature (Dul, 2003b). In a report on the competitiveness of UK technology companies, the UK Department of Trade and Industry (2005) urged companies to place people-centred design at the heart of their Research and Development and innovation activities, and promote a peoplecentred culture throughout their organizations. For services, customer-friendly service interactions can be a feature to create competitive advantage to which ergonomics could contribute. Hence ergonomics could be linked to a company's differentiation strategy by adding user-friendly features to products and services.

\subsection{Cost Strategy}

According to Porter (1985) another way to compete is to have a cost strategy: the company competes on the basis of the cost of the product or service.

By ergonomic design of the production system and the elimination of unhealthy or hazardous tasks, the costs per unit can be reduced and labour productivity increased (Abrahamsson, 2000; Beevis, 2003; De Looze, et al. 2003; GAO, 1997; Hendrick, 1996; Koningsveld et al. 2005). Put (2007) found that in manufacturing industries where both humans and machines are important elements of the production process, an ergonomic work environment is a necessary condition for cost leadership. The cost reductions are often larger for performance factors than from health and safety savings alone (Helander and Burri, 1995; Hendrick, 2003; Oxenburgh et al., 2004). Hence, ergonomics could be linked to a company's cost strategy by increasing labour productivity and reducing labour costs.

\subsection{Resource-based View of the Firm}

The resource-based view (RBV) of the firm (Barney, 1991; Barney and Wright, 1998) assumes that a company can outperform other companies by the way the company combines it technical, human and other resources. The RBV attempts to reach sustained competitive advantage by choosing and developing resources that are valuable, rare, costly to imitate, and exploitable by the organization. Compared to technology resources, human resources and their intellectual capital are much more difficult to copy (Pfeffer, 1995). 
When people are considered a key resource, ergonomics can contribute to the maximization of their use and to prevent their outflow. Thus ergonomics, with its ability to support employee retention, can help provide firms with a sustainable competitive advantage in the form of experienced, skilled employees who can perform their best for the company.

\subsection{Service Profit Chain}

Heskett et al. (1994) proposed the Service Profit Chain (SPC) model that relates employee satisfaction to customer satisfaction and further to financial performance of a service organization. This concept for service operations has been widely accepted (see for example Pugh et al., 2002) and empirical studies suggest that the relationships between employee satisfaction, customer satisfaction and business performance exist if the employee-customer contact is more important (Dean, 2004; Yee et al. 2008). Several organizational dynamics scholars have shown a renewed interest in the concept that "a happy worker is a productive worker" (Gavin and Mason, 2004; Quick and Quick, 2004; Wright et al., 2002). This concept may be particularly of interest for workers who are in contact with the customer during service delivery.

By its definition, ergonomics can contribute to worker well-being and thereby contribute to the strategy concept of the SPC (Hogenes et al., 2006). In one empirical example of the SPC, a multiple case study showed that managers in service-based warehouses chose ergonomics improvements because of the expected effect on customer satisfaction, not because of health and safety (Janssen et al., 2004). Hence, by increasing employee well-being, ergonomics can be linked to a service profit chain strategy.

\section{Conceptual Model of Strategy-Ergonomics Relations}

The previous sections show that there are opportunities to link ergonomics to strategy concepts and strategy implementations, though the evidence is still very limited, and not much experience has been reported in the literature on how to realize the link.

We do not see ergonomics, in and of itself, as a strategy. However, since attention to ergonomics can contribute to many different strategies and business outcomes, we see 
ergonomics as an important feature of the strategy formulation and implementation process. Thus, strategically speaking, attention to ergonomics can be an important element of how a company realizes its competitive advantage. It lies neither on the side of other strategies, nor is it sufficiently aggregated that it can be managed with a separate 'ergonomics process'. In these terms, ergonomics becomes a tool, or a means, rather than an 'end' in and of itself. Capturing the full benefits of ergonomics therefore will require the deliberate integration of ergonomics into core strategy arenas of the organization. This is shown in Figure 3, which is our final model where ergonomics and related OHS goals are partially integrated and embedded in the planning and control cycles of an organization. Here, ergonomics has gained a position on the 'positive' side of the business and contributes directly to the primary business outcomes.

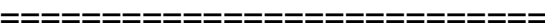

\section{INSERT FIGURE 3 ABOUT HERE}

The scale of application of ergonomics suggested here implies the engagement of many groups and individuals in the organisation. It will take a long time before the situation depicted in Figure 3 is understood and realized on a large scale. However, we believe that explicit linking of ergonomics to the strategy and desired business outcomes is a promising way to realize sustainable growth for firms without the high social costs due to work-related ill health. We see this approach as a way to improve the impact of the ergonomics discipline and its ergonomists in the world of business.

\section{Implications for the Ergonomist}

The question arises of how the ergonomics field can move from the present situation shown in Figure 1 (isolated) to the desired situation shown in Figure 3 (embedded). We believe that ergonomists in research, education and practice (both internal ergonomists that are part of the organization and external consultants), who accept the broad definition of ergonomics presented in the introduction have a crucial role in a) developing the possible links between ergonomics and company's strategies, b) finding evidence for these links, and c) 
communicating the links to the business stakeholders who are involved in strategy formulation and implementation. The experience of Volvo's senior ergonomist illustrates this challenge:

"The ergonomics work is not a separate entity, but is based on the strategy. It was much easier to get the management and other employees to understand, realise, accept and become involved in ergonomics work when they saw the link with the ... strategy." (Munck-Ulfsfält et al., 2003).

Although our models suggest static links between ergonomics and strategy, in reality the situation can be more dynamic. The ergonomist must consider the dynamic context of the firm and understand the different strategic objectives of stakeholders. Some stakeholders can address health and safety ergonomics based on legislation while simultaneously others pursuing system performance applications. The ergonomist can use a flexible approach to study, teach and practice the integration of ergonomics in organizations and use different languages for different goals. This implies a need for ergonomists to learn to speak new languages with different stakeholders - a task some ergonomists find challenging (Laring et al. 2007; Neumann 2004). This paper provides a conceptual framework to help ergonomists in research, education and practice to understand how to support the strategic objectives of a company.

The exploration of the links between ergonomics and strategy could start with reading business and management magazines and journals; visiting management and business conferences; reading business documents such as the company's annual report and other strategic documents; and engaging with business and management's internal and external networks. Finding evidence for the links between strategy and ergonomics can be done by looking at variables that are directly linked to the business strategy and business goals during the analysis and design of an environment. Engaging senior managers and other stakeholders in discussions surrounding their strategic objectives and how ergonomics applications could support these objectives is both a good way to understand the manager's goals and thinking, and also to demonstrate that the ergonomist's attention is beyond health and safety. The link between ergonomics and strategy must be widely communicated to business managers, and in their own language, rather than the language of health and safety ergonomics. By learning the 
'language' of the various strategy stakeholders, the ergonomists will be better equipped to communicate the potential contribution ergonomics can make in each strategic arena. Furthermore, ergonomists can influence strategy by being more than ergonomics experts. The ergonomist can also act as a 'Political Reflective Navigator', who is networking to convince stakeholders about the value of ergonomics (Broberg and Hermund 2004), both in their respective functions and in cross-functional co-operations.

The successful ergonomist in research, education or practice is aware of business strategies and desired business outcomes; knows who are main stakeholders; knows what the benefits of ergonomics may be for these stakeholders; knows how ergonomics can be implemented to realize these benefits; and can communicate with the stakeholders in their own language and networks. By understanding stakeholders' needs and goals and supporting them with good ergonomics, the ergonomists can become indispensable. In other words the ergonomist should become a real partner in the business and management world. In itself, the idea of linking ergonomics to business goals is not new. In the tradition of the ergonomics field, 'system performance' has always been part of the field. The contribution of our paper is that we show what 'system performance' can mean in the context of companies. We indicate how ergonomics can become part of to the core decision processes in a company, by focusing on the possible links between ergonomics and different levels and types of strategies that can coexist in a company.

\section{Conclusions}

Ergonomics can contribute to many different company strategies and support the objectives of different business functions and of the organisation as a whole. The proposed linking of ergonomics explicitly to specific business strategies and desired business outcomes, as suggested by the IEA description of ergonomics, remains a great challenge for the ergonomics discipline. For many ergonomists in research, education and practice, it means a paradigm shift, which requires a re-positioning from a primary health ergonomics approach to a more businessoriented ergonomics approach. We argue that, by contributing to the shared goals of business 
performance, ergonomists will also be better able to reach their traditional health and safery objectives. 


\section{Acknowledgements}

This work has been supported by Erasmus Research Institute of Management of the Erasmus University Rotterdam, and the SMARTA theme of the Swedish National Institute for Working Life. We would like to thank the two anonymous reviewers for their valuable comments on an earlier version of the paper. 


\section{References}

Abrahamsson, L., 2000. Production economics analysis of investment initiated to improve working environment. Applied Ergonomics. 31(1), 1-7.

Amabile, T.M., Conti, R., Coon, H., Lazenby, J., Herron, M., 1996) Assessing the work environment for creativity. Academy of Management Journal, 39, 1154-1184.

Adler, P.S., Goldoftas, B., 1997. Ergonomics, employee involvement, and the Toyota production system: A case study of NUMMI's 1993 model introduction. Industrial \& Labor Relations Review, 50 (3), 416-437.

Appelbaum, E., Bailey, T., Kalleberg, A.L., Berg, P., 2000. Manufacturing Advantage: Why High-Performance Work Systems Pay Off: Cornell University Press.

Axelsson, J.R.C., 2000. Quality and ergonomics: towards successful integration, in Linköping studies in science and technology, Dissertations, 616, University of Linköping: Linköping.

Barney, J.B., 1991. Firm resources and sustained competitive advantage. Journal of Management, 17(1), 99-120.

Barney, J. B., P. M. Wright, 1998. On becoming a strategic partner: The role of human resources in gaining competitive advantage. Human Resource Management 37(1), 3146.

Beevis, D., 2003. Ergonomics - Costs and benefits revisited. Applied Ergonomics 34(5), 491496.

Boudreau, J., Hopp, W., McLain, J.O. and Thomas, L.J., 2003. On the interface between operations management and human resources management. Manufacturing \& Service Operations Management, 5(3), 179-202.

Brassler, A., Schneider, H., 2001) Valuation of strategic production decisions. International Journal of Production Economics, Vol 69 (1), 119-127.

Breedveld, P., Dul, J., 2005. The position and success of certified European ergonomists Rotterdam: Rotterdam School of Management, Erasmus University, Rotterdam 22p. 
Broberg, O., 1997. Integrating ergonomics into the product development process. International Journal of Industrial Ergonomics, 19(4), 317-327.

Broberg, O., Hermund, I., 2004. The OHS consultant as a 'political reflective navigator' in technological change processes. International Journal of Industrial Ergonomics, 33 (4), 315-326.

Carayon, P., Sainfort, F., Smith, M. J., 1999. Macroergonomics and total quality management: how to improve quality of working life? International Journal of Occupational Safety And Ergonomics, 5 (2), 303-334.

Ceylan, C., Dul, J., Aytac, S. 2007. Can the office environment stimulate a manager's creativity? Human Factors and Ergonomics in Manufacturing (accepted)

Cummings, A., Oldham, G. R. 1997. Enhancing creativity: Managing work contexts for the high potential employee. California Management Review, 40(1),22-38.

Conti, R., Angelis, J., Cooper, C., Faragher, B., Gill, C., 2006. The effects of lean production on worker job stress. International Journal of Operations \& Production Management, 26 (9), 1013-1038.

Datta, D. K., Guthrie, J. P., Wright, P. M., 2005. Human resource management and labor productivity: Does industry matter? Academy of Management Journal, 48 (1), 135-145.

Dean A.M., 2004. Links between organisational and customer variables in service delivery Evidence, contradictions and challenges. International Journal of Service Industry Management, 15(3-4), 332-350.

De Looze M.P., Van Rhijn J.W., Van Deursen J., Tuinzaad G.H., Reijneveld C.N., 2003. A participatory and integrative approach to improve productivity and ergonomics in assembly. Production Planning \& Control 14(2), 174-181.

Den Hartog, D. N., Verburg, R.M., 2004. High performance work systems, organisational culture and firm effectiveness. Human Resource Management Journal, 14 (1), 55-79.

Drury C.G., 2000. Global quality: linking ergonomics and production. International Journal of Production Research, 38(17), 4007-4018.

Dul , J., 2003a. Ergonomics in Management. Proceedings of the XVth Triennial Congress of the International Ergonomics Association, Seoul, Korea, The Ergonomics Society of Korea. 
Dul J., 2003b. The strategic value of ergonomics for companies, in Human Factors in Organisational Design and Management VII, H. Luczak and K.J. Zink, Editors. IEA Press: Aachen, Germany. p765-769.

Dul, J., Neumann, W.P., 2005. Ergonomics contributions to company strategies. In: Proceedings of the 10th International Conference on Human Aspects of Advanced Manufacturing: Agility and Hybrid Automation (HAAMAHA 2005). San Diego, USA, July 18-21, 2005.

Dul, J., Ceylan, C. 2006. Enhancing organizational creativity from an ergonomics perspective: The Creativity Development model. Paper presented at the 16th World Congress on Ergonomics (IEA 2006), Maastricht, The Netherlands, July 10-14.

Dul , J., Ceylan, C., Hendriks, H., 2007. A practical instrument to measure the creativity potential of the work environment. In: Proceedings of the 10th European conference on Creativity and Innovation, Copenhagen, Denmark.

Eisenberger, R., Fasolo, P., Davis-LaMastro, V., 1990. Perceived Organizational Support and Employee Diligence, Commitment, and Innovation. Journal of Applied Psychology, 75 (1), 51-59.

Eklund, J. A. E., 1995. Relationships between Ergonomics and Quality in Assembly Work. Applied Ergonomics, 26 (1), 15-20.

Ekman Philips, M., 1990. Dialog och uppslutning : arbetsorganisatorisk förnyelse i industriarbete. Stockholm, Arbetsmiljöfonden.

Ellegård, K.D., Jonsson, T., Engström, M.I., Johansson, L. Medbo, Johansson, B., 1992. Reflective production in the final assembly of motor vehicles - en emerging Swedish challenge. International Journal of Operations and Production Management $12(7,8)$, $117-134$

Eskildsen, J. K., Dahlgaard, J. J., 2000. A causal model for employee satisfaction. Total Quality Management, 11 (8), 1081.

GAO, 1997. Private Sector Ergonomics Programs Yield Positive Results. Washington, US General Accounting Office - Health Education and Human Services Division. 
Gavin, J. H., Mason, R. O., 2004. The virtuous organization: The value of happiness in the workplace. Organizational Dynamics 33 (4), 379-392.

Ghobadian, A., Gallear, D., 2001. TQM implementation: an empirical examination and proposed generic model. Omega, 29, 343-359.

Gino, F., Pisano, G., 2008. Toward a theory of behavioral operations. Manufacturing \& Service Operations Management (in print).

Goldschmidt, G., Nielsen, A., Fredricksen, J., Bonnesen, J., 2002. In: Proceedings of the 34th annual congress of the Nordic ergonomics society, Vol. 1 (Eds, Cadenfors, D., Eklund, J. and Kiviloog, L.), Linköping University, Kolmården, SE, 291-295.

Hardjono, T., De Klein, P., 2004. Introduction on the European Corporate Sustainability Framework (ECSF). Journal of Business Ethics, 55 (2), 99-113.

Helander, M. G., Burri, G. J., 1995) Cost-Effectiveness of Ergonomics and Quality Improvements in Electronics Manufacturing. International journal of industrial ergonomics, Vol 15 (2), 137-151.

Helander, M., 1999. Seven common reasons to not implement ergonomics. International Journal of Industrial Ergonomics, 25(1), 97-101.

Helander, M., Nagamachi, M., 1992. Design for Manufacturability: A systems approach to concurrent engineering and ergonomics. Taylor \& Francis.

Helander, M., 2006. A Guide to Human Factors and Ergonomics 2nd ed., Taylor \& Francis, Toronto.

Hendrick, H., 1996. Good ergonomics is good economics. Human Factors and Ergonomics Society: Santa Monica, CA, USA.

Hendrick, H. W., 2003. Determining the cost-benefits of ergonomics projects and factors that lead to their success. Applied Ergonomics 34(5), 419-427.

Heskett, J.L, Jones, T.O, Loveman, G.W, Sasser, W.E., Schlesinger, L.A., 1994. Putting the Service-Profit Chain to Work. Harvard Business Review, 72(2), 164-174.

Hogenes, E., Dul, J., Haan, G., 2006. Human centered designed work environments at Interpolis. In: Proceedings of the 16th world congress on ergonomics, 10-14 July, Maastricht, The Netherlands. 
IEA Council, 2000. The Discipline of Ergonomics. International Ergonomics Society, 1 p.

Imbeau, D., Bellemare, M., Courville, J., Bergeron, S., Desjardins, L., 2001. Ergonomics in a design environment. In: Karwowski, W. (Ed.), International Encyclopedia of Ergonomics and Human Factors, Vol. 1 Taylor \& Francis, London.

Janssen, K. Van de Vecht, H, Wong, Y.W., 2004. Employee and customer satisfaction are the most important motives for solving ergonomics problems. Bachelor thesis Rotterdam School of Management, Erasmus University, Rotterdam: Erasmus University Rotterdam.

Jenkins, S., Rickards, J., 2001. The economics of ergonomics: three workplace design case studies. In Alexander, D. C. and Rabourn, R. (Ed.) Applied ErgonomicsTaylor \& Francis, London, 336.

Jensen, P. L., 2002. Human factors and ergonomics in the planning of production. International Journal of Industrial Ergonomics, 29 (3), 121-131.

Joseph, B. S., 2003. Corporate ergonomics programme at Ford Motor Company. Applied Ergonomics, 34 (1), 23-28.

Kivimäki, M., Vahtera, J., Ferrie, J. E., Pentii, J., 2001. Organisational downsizing and muscusloskeletal problems in employees: a prospective study. Occupational and Environmental Medicine, 58, 811-817.

Koningsveld, E. A. P., Dul, J., Van Rhijn, G. W., Vink, P., 2005. Enhancing the impact of ergonomics interventions. Ergonomics, 48 (5), 559-580.

Kristensson, P., Magnusson, P.R., Matthing, J., 2002) Users as a hidden resource for creativity: Findings from an Experimental Study on User Involvement. Creativity and Innovation Management $11(1), 55-61$.

Kuo, C.-F., C.-H. Chu, 2005. An online ergonomics evaluator for 3D product design. Computers in Industry 56(5), 479-792.

Landsbergis, P.A, Cahill, J., Schnall, P., 1999. The Impact of Lean Production and Related New Systems of Work Organization on Worker Health. Journal of Occupational Health Psychology, 4(2), 108-130. 
Larco, J.A.,Roodbergen, K.J., De Koster, M.B.M., Dul, J., 2008. Employees' well-being and warehouse efficiency come together. Working paper. Rotterdam School of Management, Erasmus University.

Laring, J., Neumann, W. P., Nagdee, T., Wells, R., Theberge, N., 2007) Human factors tool use among Swedish ergonomists - An interview study. In Proceedings of the 38th annual conference of the Association of Canadian Ergonomists (ACE), Association of Canadian Ergonomists, Toronto.

Lee, K.S., 2005) Ergonomics in total quality management: How can we sell ergonomics to management? Ergonomics, 48 (5), 547-558.

Liker, J.K., 2004) The Toyota Way. 14 Management principles from the world's greatest manufacturer. McGraw-Hill.

Lin, L., Drury, C., Kim, S.-W., 2001. Ergonomics and Quality in Paced Assembly Lines. Human Factors and Ergonomics in Manufacturing, 11 (4), 377-382

Miles, B. L., Swift, K., 1998. Design for manufacture and assembly. Manufacturing Engineer, 77(5), 221-224.

Munck-Ulfsfält, U., Falck, A., Forsberg, A., Dahlin, C., Eriksson, A., 2003. Corporate ergonomics program at Volvo Car Corporation. Applied Ergonomics, 34, 17-22

Neumann, W.P, Kihlberg, S., Medbo, P., Mathiassen S.E., Winkel J., 2002. A Case Study evaluating the ergonomic and productivity impacts of partial automation strategies in the electronics industry. International Journal of Production Research, 40(16), 4059-4075.

Neumann, W. P., Wells, R., Norman, R., Jeans, D., Dubblestyne, D., Harvey, H., Peter, O., 1999. Roles and relationships for making ergonomics change. Results of a 2-day focus session with industry personnel. In: Proceedings of the 31st Annual Conference of the Association of Canadian Ergonomists, Hull, Canada.

Neumann, W. P., Winkel, J., Medbo, L., Mathiassen, S. E., Magneberg, R., 2006. Production system design elements influencing productivity and ergonomics - A case study of parallel and serial flow strategies. International Journal of Operations \& Production Management, 26, 8), 904-923.

Norman, D. A., 2002. The design of everyday things. New York, basic Books. 
Noro, K., Imada, A. S., 1991. Participatory Ergonomics, Taylor \& Francis, London.

Oxenburgh, M., Marlow, P., Oxenburgh, A., 2004) Increasing Productivity and Profit Through Health and Safety: The Financial Returns from a Safe Working Environment. CRC Press.

Parker, S. K., 2003. Longitudinal effects of lean production on employee outcomes and the mediating role of work characteristics. Journal of Applied Psychology, 88, 4), 620-634.

Pepper, L., Messinger, M., Weinberg, J., Campbell, R., 2003. Downsizing and health at the United States Department of Energy. American Journal of Industrial Medicine, 44, 481491.

Perrow, C., 1983. The organizational context of human factors engineering. Administrative Science Quarterly, 28(4), 521-541.

Pfeffer, J., 1995. Producing sustainable competitive advantage through the effective management of people. Academy of Management Executive 9(1), 55-72.

Porter, M.E., 1985. Corporate Advantage: Creating and Sustaining Superior Performance. New York: Free Press.

Preuss, G. A., 2003. High performance work systems and organizational outcomes: The mediating role of information quality. Industrial \& Labor Relations Review, 56, 4), 590605.

Put, M., 2007. The contribution of ergonomics to a cost leadership strategy. Master thesis. Rotterdam School of Management, Erasmus University, the Netherlands.

Pugh, S. D., Dietz, J., Wiley, J. W., Brooks, S. M., 2002. Driving service effectiveness through employee-customer linkages. Academy of Management Executive, 16, 4), 73-84

Quick, J. C., Quick, J. D., 2004. Healthy, happy, productive work: A leadership challenge. Organizational Dynamics, 33, 4), 329-337.

Rho, B.H, Park, K., Yu, Y.M., 2001. An international comparison of the effect of manufacturing strategy-implementation gap on business performance. International Journal of Production Economics, 70, 89-97. 
Ruiz-Carrillo, J. I. C., Fernández-Ortiz, R., 2005. Theoretical foundation of the EFQM model: The resource-based view. Total Quality Management and Business Excellence, 16, 1), 31-55.

Scalia, E., 2001. OSHA's Ergonomics Litigation Record: Three Strikes and It's Out. Journal of Labor Research, 22, 1), 55-74.

Shalley, C. E., Zhou, J., Oldham, G. R., 2004) The effects of personal and contextual characteristics on creativity. Journal of Management 30, 933-958.

Sen, R. N., Yeow, P. H. P., 2003) Cost effectiveness of ergonomic redesign of electronic motherboard. Applied Ergonomics, Vol 34, 5), 453-463

Senge, P. M., 1990. The Fifth Discipline - The Art \& Practice of the Learning Organisation. London, Century Business.

Sminia, H., 2005. Strategy formation as layered discussion. Scandinavian Journal of Management 21, 267-291.

Sundin, A., Christmansson, M., Larsson, M., 2004. A different perspective in participatory ergonomics in product development improves assembly work in the automotive industry. International Journal of Industrial Ergonomics, 33, 1), 1-14.

Swaen, V., Vanhamme, J., 2004. See How 'Good' We Are: The Dangers of Using Corporate Social Activities in Communication Campaigns. Advances in Consumer Research, 31, 1), 302-313.

UK Department of Trade and Industry, 2005. People-Centered Innovation. Moving Beyond Technology-Led Innovation. Strategic Direction 21(4), 30-32

Vahtera, J., Kivimäki, M., Pentti, J., 1997. Effect of organisational downsizing on health of employees. The Lancet, 350, October 18), 1124-1128.

Von Hippel, E., 1986) Lead users: A source of novel product concepts. Management Science, 32, 7), 791-805.

Way, S. A., 2002. High performance work systems and intermediate indicators of firm performance within the US small business sector. Journal of Management, 28, 6), 765785. 
Womack, J. P., Jones, D. T., Roos, D., 1990. The machine that changed the world, Rawson Associates, New York.

Whysall, Z. J., Haslam, R. A., Haslam, C., 2004. Processes, barriers, and outcomes described by ergonomics consultants in preventing work-related musculoskeletal disorders. Applied Ergonomics, 36, 343-351.

Wright, T. A., Cropanzano, R., Denney, P. J., Moline, G. L., 2002. When a happy worker is a productive worker: A preliminary examination of three models. Canadian Journal of Behavioural Science-Revue Canadienne Des Sciences Du Comportement, 34, 3), 146150.

Yee, R.W.Y., Yeung, A.C.L., Cheng, T.C.E., 2008. The impact of employee satisfaction on quality and profitability in high-contact service industries. Journal of Operations Management, in print) .

Yeow, P.H.P., Sen, R.N., 2003. Quality, productivity, occupational health and safety and cost effectiveness of ergonomics improvements in the test workstations of an electronic factory. International Journal of Industrial Ergonomics, 2003. 32(2), 147-163. 


\section{Figures}

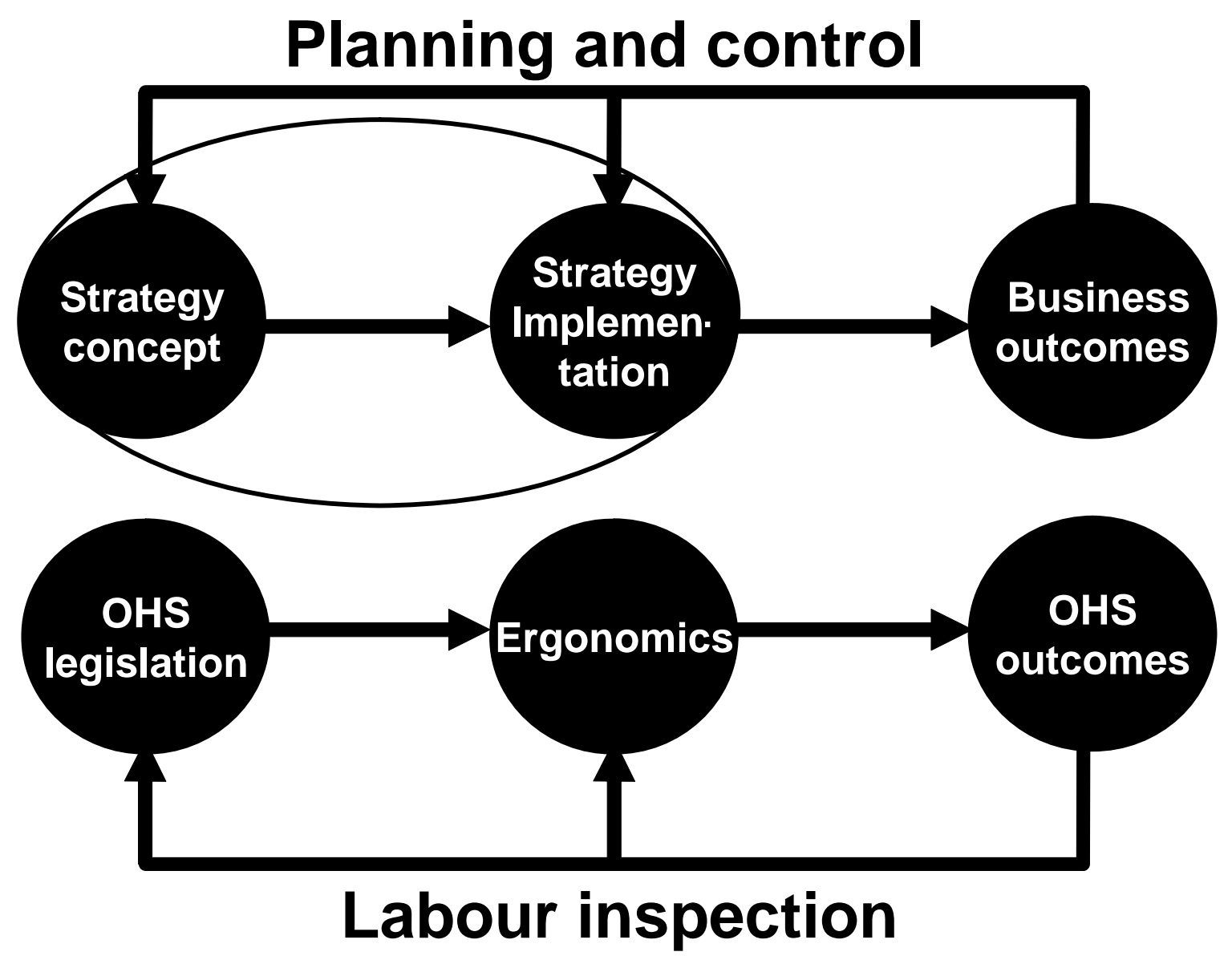

Figure 1

Upper part: The relationship between strategy, strategy concept and strategy implementation) and business outcomes. Lower part: The present isolated position of ergonomics. OHS = Occupational Health and Safety. 


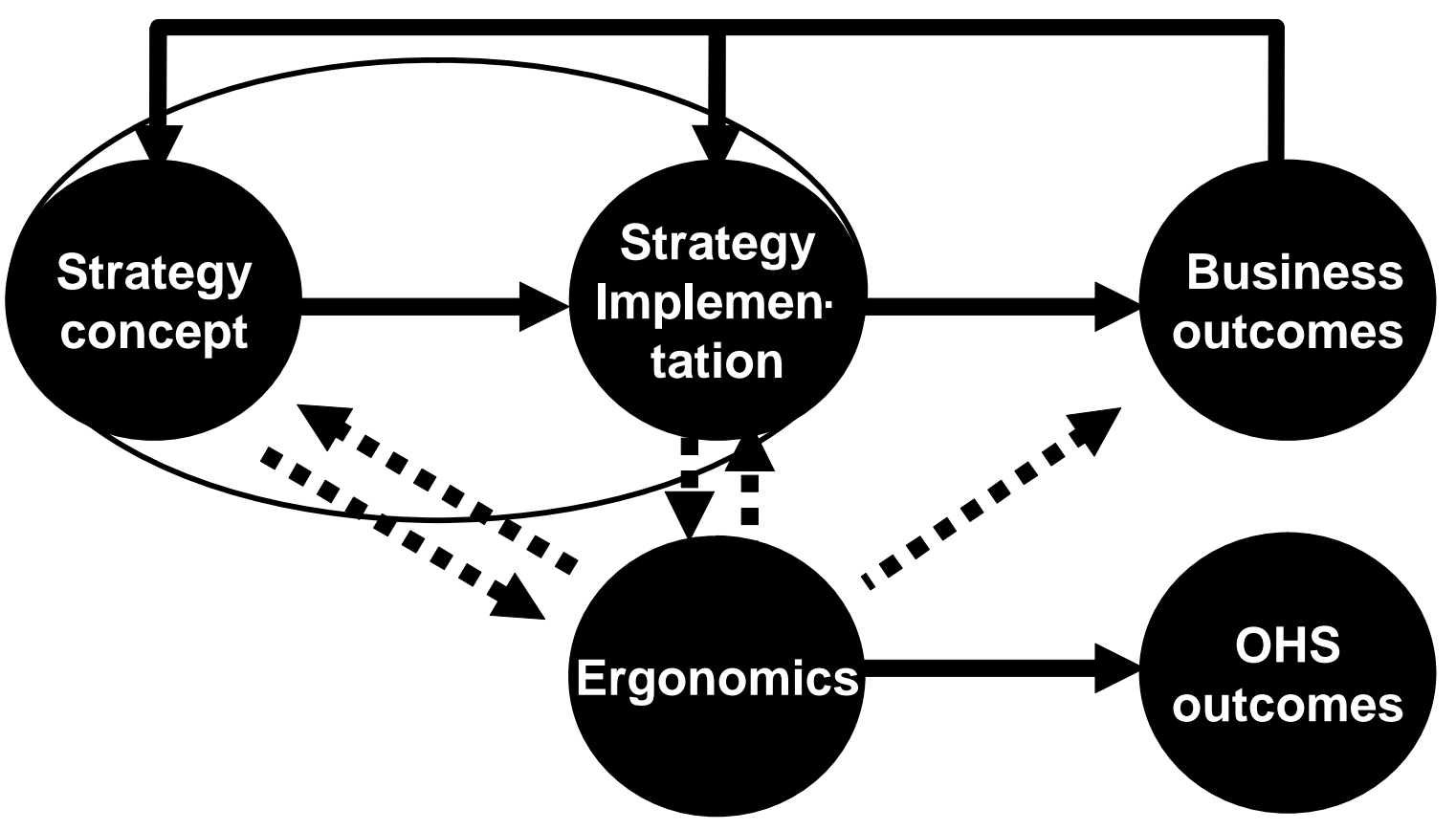

Figure 2

First step of linking ergonomics to strategy and business outcomes involves consideration of the relationships between ergonomics and strategic concepts, implementation, and business outcomes. 


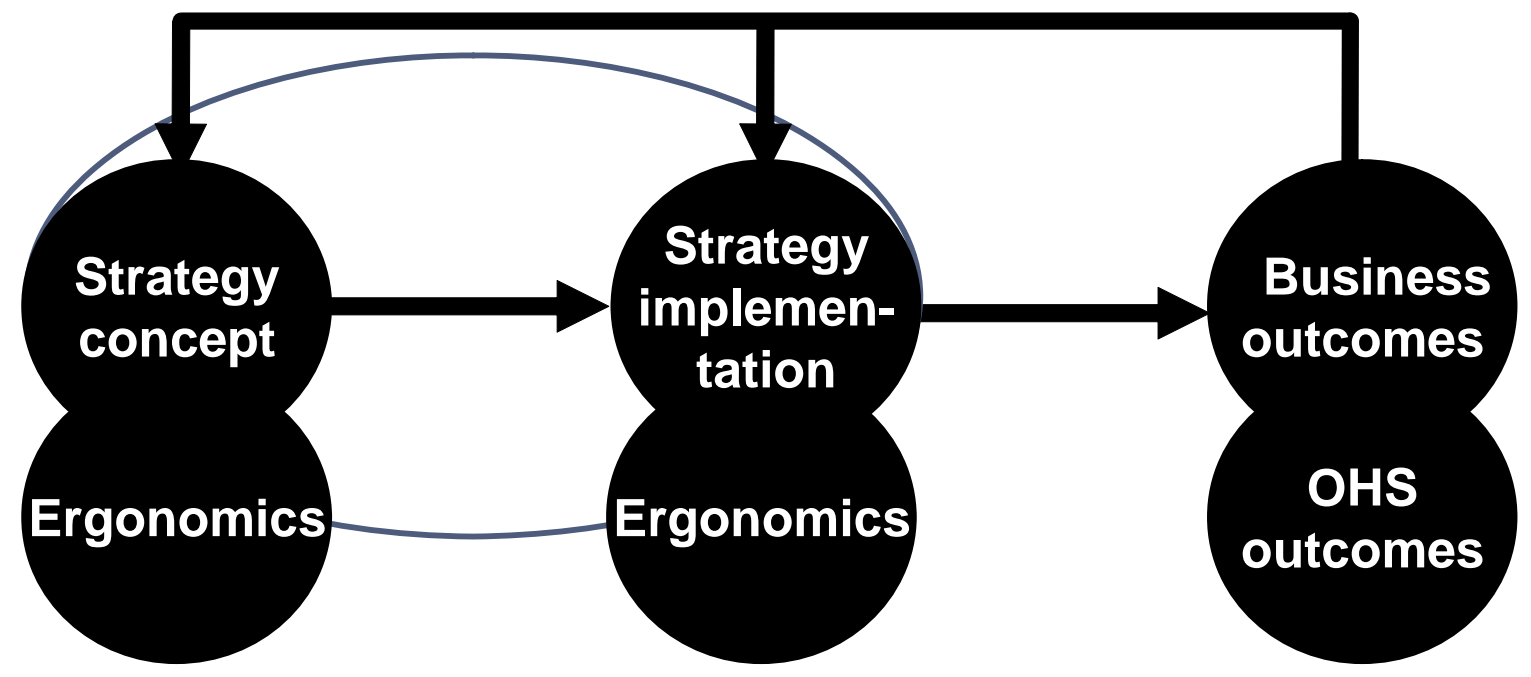

Figure 3

Final model of linking ergonomics to strategy and business outcomes. 


\section{Publications in the Report Series Research ${ }^{*}$ in Management}

\section{ERIM Research Program: "Business Processes, Logistics and Information Systems"}

2008

An Evolutionary Framework for Determining Heterogeneous Strategies in Multi-Agent Marketplaces

Alexander Babanov, Wolfgang Ketter and Maria Gini

ERS-2008-002-LIS

http://hdl.handle.net/1765/10972

Choosing between Auctions and Negotiations in Online B2B Markets for IT Services: The Effect of Prior Relationships and Performance

Uladzimir Radkevitch, Eric van Heck and Otto Koppius

ERS-2008-004-LIS

http://hdl.handle.net/1765/11288

Key Issues in Expansion of End-User Mobile Communication in China

Sunanda Sangwan, Guan Chong and Louis-Francois Pau

ERS-2008-011-LIS

http://hdl.handle.net/1765/11762

Some Comments on the Question Whether Co-Occurrence Data Should Be Normalized

Ludo Waltman and Nees Jan van Eck

ERS-2008-014-LIS

http://hdl.handle.net/1765/11810

Bibliometric Mapping of the Computational Intelligence Field

Nees Jan van Eck and Ludo Waltman

ERS-2008-015-LIS

http://hdl.handle.net/1765/11811

Demand Management Opportunities in E-fulfillment: What Internet Retailers Can Learn from Revenue Management Niels Agatz, Ann Campbell, Moritz Fleischmann, Jo van Nunen and Martin Savelsbergh ERS-2008-021-LIS

http://hdl.handle.net/1765/12244

Time Slot Management in Attended Home Delivery

Niels Agatz, Ann Campbell, Moritz Fleischmann and Martin Savelsbergh

ERS-2008-022-LIS

http://hdl.handle.net/1765/12245

Mobile Service Affordability for the Needy, Addiction, and ICT Policy Implications

L-F Pau

ERS-2008-023-LIS

http://hdl.handle.net/1765/12246

CBPRS: A City Based Parking and Routing System

J.L. Boehlé, L.J.M. Rothkrantz and M. van Wezel

ERS-2008-029-LIS

http://hdl.handle.net/1765/12467

Coping with Costly Bid Evaluation in Online Reverse Auctions for IT Services

Uladzimir Radkevitch, Eric van Heck and Otto Koppius

ERS-2008-039-LIS

http://hdl.handle.net/1765/12871 
Multi Agent Systems in Logistics: A Literature and State-of-the-art Review Niels Lang, Hans M. Moonen, F. Jordan Srour and Rob A. Zuidwijk

ERS-2008-043-LIS

http://hdl.handle.net/1765/12902

Generalizing the $h$ - and $g$-indices

Nees Jan van Eck and Ludo Waltman

ERS-2008-049-LIS

http://hdl.handle.net/1765/13210

Applying Revenue Management to the Reverse Supply Chain

Mark Ferguson, Moritz Fleischmann and Gilvan C. Souza

ERS-2008-052-LIS

http://hdl.handle.net/1765/13211

Ergonomics Contributions to Company Strategies

Jan Dul and W. Patrick Neumann

ERS-2008-058-LIS

http://hdl.handle.net/1765/13213

Can the Office Environment Stimulate a Manager's Creativity?

Canan Ceylan, Jan Dul and Serpil Aytac

ERS-2008-059-LIS

http://hdl.handle.net/1765/13215

* A complete overview of the ERIM Report Series Research in Management: https://ep.eur.n//handle/1765/1

ERIM Research Programs:

LIS Business Processes, Logistics and Information Systems

ORG Organizing for Performance

MKT Marketing

F\&A Finance and Accounting

STR Strategy and Entrepreneurship 